\title{
Pengaruh Pembelajaran Kooperatif Tipe Numbered Head Together dan Make A Match Terhadap \\ Prestasi Belajar Sistem Komputer Ditinjau dari Kecerdasan Emosional
}

\author{
Imam Afandi10, Budiyono ${ }^{11}$, Sunardi12 \\ Imam.affandi.email@gmail.com
}

\begin{abstract}
The teacher's role is only as a facilitator, mediator and guide. Because the approach used is student-centered, the teacher only assists the change process with scaffolding and guiding so students can achieve a more perfect understanding than previous understanding. The Cooperative Learning model is one of the learning models that emphasizes the active role of students in learning. Among the cooperative learning models are the type of NHT and Make A Match. This research is an experimental research, $2 \times 3$ factorial design. The Population of this research is all of vocational school students in Sub Rayon 1 of Ngawi Regency in Odd Semester of Academic Year 2013/2014. Research is done by providing the same learning materials for experimentation and control classes. Experimental Classes with the NHT Cooperative Model Approach while the control classes used the Make A Match Cooperative Model Approach. The results are (1) there is a difference in effect between the use of the NHT (Numbered Head Together) type of cooperative learning model and Make a Match on student achievement. (2). There are differences in the learning achievements of students who have high, moderate and low emotional intelligence on computer system subjects. (3). There is an interaction of influence between the use of NHT cooperative learning models and Make a Match with the level of emotional intelligence of students on student achievement in Computer System subjects in terms of students' emotional intelligence.
\end{abstract}

Keywords: Numbered Head Together (NHT), Match a Match, learning achievement, emotional intelligence

\footnotetext{
10 Mahasiswa Magister Teknologi Pendidikan Universitas Sebelas Maret

11 Dosen Universitas Sebelas Maret Surakarta

12 Dosen Universitas Sebelas Maret Surakarta
} 


\section{PENDAHULUAN}

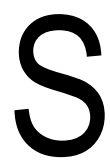

alah satu lembaga pendidikan tersebut adalah Sekolah Menengah Kejuruan (SMK) yang bertujuan untuk membekali siswanya untuk siap kerja di masyarakat maupun dunia usaha. UU No. 20 tahun 2003 menyatakan bahwa "Pendidikan menengah kejuruan merupakan pendidikan menengah yang mempersiapkan peserta didik untuk dapat bekerja dalam bidang tertentu". Kenyataan yang ada tampaknya belum sesuai dengan apa yang diharapkan pada pendidikan menengah kejuruan. Hal ini dapat dilihat dengan banyaknya lulusan SMK yang masih menganggur. Pemerintah telah melakukan usaha untuk meningkatkan kualitas pendidikan diantaranya: penggunaan kurikulum yang disesuaikan dengan kebutuhan peserta didik di setiap daerah, adanya penetapan sekolah unggulan, pemberian sertifikan ISO terhadap sekolah dan pemberian standar nasional maupun internasional terhadap sekolah. Salah satu tolok ukur yang digunakan dalam meneliti keberhasilan pendidikan di SMK yang bergerak dalam bidang komputer adalah prestasi belajar siswa selama di sekolah.

Prestasi belajar merupakan tingkat keberhasilan siswa dalam menguasai materi pelajaran selama mengikuti proses belajar yang diwujudkan dengan angka atau nilai. Prestasi belajar dipengaruhi oleh dua faktor, yaitu faktor intern dan faktor ekstern (Alder, 2001). Proses pembelajaran yang dilakukan hendaknya sesuai dengan kondisi dan kebutuhan siswa (student-centered). Ferguson (2011) mengungkapkan bahwa pembelajaran yang berpusat pada siswa menempatkan siswa sebagai pusat bagi pengajaran guru dan perencaaan proses pembelajaran. Poin penting dari teori Ferguson menyebutkan bahwa anak adalah seorang pembelajar dan pemikir aktif. Mereka mengkonstruksi pengetahuan mereka sendiri dari objek atau pengalaman yang didapatkan. Salah satu pendekatan pembelajaran yang berpusat kepada siswa (student-centered) adalah model pembelajaran kooperatif.

Pembelajaran kooperatif (Cooperative learning) adalah model pembelajaran yang menekankan pada saling ketergantungan positif antar individu siswa, adanya tanggung jawab perseorangan, tatap muka, komunikasi intensif antar siswa, dan evaluasi proses kelompok (Rohman, 2009). Selain prestasi belajar yang menekankan Kecerdasan Intelektual (IQ) ada lagi Kecerdasan Emosional (EQ) yang dimiliki seseorang dalam dirinya (Kane, 2013). Kecerdasan emosional sangat mendukung keberhasilan belajar siswa karena siswa dengan kecerdasan emosional yang berkembang baik akan berhasil dalam kehidupan dan memiliki motivasi tinggi untuk berprestasi (lqbal, Kousar, \& Rahman, 2011). Pernyataan ini didukung oleh sebuah laporan dari National Center for Clinical Infant Programs yang ditulis oleh Goleman (2008) bahwa keberhasilan di sekolah bukan diramalkan oleh kumpulan fakta seorang siswa atau kemampuan dininya untuk membaca, melainkan oleh ukuran-ukuran emosional dan sosial yakni pada diri sendiri dan minat; tahu perilaku yang diharapkan orang lain dan bagaimana mengendalikan dorongan hati untuk tidak berbuat nakal; mampu menunggu; mengikuti petunjuk dan mengacu pada guru untuk mencari bantuan; serta mengungkapkan kebutuhan-kebutuhan saat bergaul dengan siswa lain. Hampir semua siswa yang prestasi sekolahnya buruk tidak memiliki satu atau lebih unsur-unsur kecerdasan emosional ini (Chen, et al. 2012).

Pendapat dari beberapa ahli tersebut sangat jauh berbeda dengan kondisi yang terjadi dalam pembelajaran di SMK di Sub Rayon 01 Kabupaten Ngawi khususnya SMKN 1 Kasreman. Dalam proses pembelajarannya, guru masih menggunakan metode konvensional dimana guru menerangkan di depan kelas dengan metode ceramah kemudian siswa mendengarkan dan mencatat apa yang disampaikan. Partisipasi siswa dalam pembelajaran sangatlah kecil. Bahkan, siswa cenderung menyibukkan diri dengan kegiatan yang tidak terkait dengan materi pelajaran yang diberikan. Kondisi tersebut berimplikasi pada pencapaian hasil belajar para siswa (Ali et al, 2011).

Prestasi belajar mata pelajaran system komputer siswa kelas $X$ tahun 2013/2014 masih belum maksimal. Hal ini terlihat bahwa masih banyak siswa yang nilainya belum mampu mencapai KKM yang ditetapkan sekolah yaitu sebesar 75 . Hal ini disebabkan oleh metode pengajaran yang berpusat pada 
guru. Metode ceramah yang cenderung monoton membuat siswa kurang antusias dalam mengikuti proses pembelajaran di dalam kelas.

Berdasarkan latar belakang diatas maka tujuan umum dan tujuan khusus pada penelitian ini adalah:

1. Tujuan umum dari penelitian ini adalah agar dapat memahami pengaruh penggunaan metode pembelajaran kooperatif tipe NHT (Numbered Head Together) dan Make a Match terhadap prestasi belajar siswa pada mata pelajaran sistem komputer dalam kompetensi sistem bilangan.

2. Tujuan khusus dari penelitian ini adalah untuk mengetahui:

a. Perbedaan pengaruh antara penggunaan metode pembelajaran kooperatif tipe NHT (Numbered Head Together) dan Make a Match terhadap prestasi belajar siswa pada mata pelajaran sistem komputer pada kompetensi Sistem Bilangan.

b. Perbedaan prestasi belajar siswa yang mempunyai kecerdasan emosional tinggi, sedang atau rendah pada pembelajaran sistem komputer kompetensi sistem bilangan?

c. Adanya interaksi antara penggunaan metode pembelajaran kooperatif tipe NHT (Numbered Head Together) dan Make a Match dengan kecerdasan emosional siswa terhadap prestasi belajar siswa pada mata pelajaran sistem komputer kompetensi sistem bilangan.

Berdasarkan latar belakang di atas, maka penulis tertarik untuk mengadakan penelitian dengan judul pengaruh pembelajaran kooperatif tipe NHT (numbered head together) dan make a match terhadap prestasi belajar sistem komputer ditinjau dari kecerdasan emosional siswa SMK jurusan TKJ sub rayon 01 Ngawi.

\section{Kecerdasan Emosional}

Menurut Agustian (2003), kecerdasan emosional adalah sebuah kemampuan untuk mendengarkan bisikan emosi dan menjadikannya sebagai sumber informasi maha penting untuk memahami diri sendiri dan orang lain demi mencapai sebuah tujuan. Goleman (2005) menekankan bahwa kecerdasan emosional merujuk pada kemampuan mengenali perasaan diri sendiri dan orang lain (Berenson et.al, 2008)., kemampuan mengelola emosi dengan baik pada diri sendiri dan dalam hubungan dengan orang lain.

\section{Pembelajaran Kooperatif}

Pembelajaran kooperatif tipe NHT (Numbered Head Together) yaitu salah satu tipe pembelajaran kooperatif yang menekankan pada struktur khusus yang dirancang untuk mempengaruhi pola interaksi siswa dan memiliki tujuan untuk meningkatkan penguasaan akademik melalui diskusi yang terdiri dari kelompok-kelompok kecil yang heterogen (Mahedy et al, 2006)., serta kesiapan siswa saat dipanggil nomor-nomornya oleh guru untuk mengetahui pemahaman siswa terhadap materi yang disampaikan. Model pembelajaran kooperatif selanjutnya yaitu tipe mencari pasangan (Make a Match) yang dikembangkan oleh Lorna Curran pada tahun 1994. Make a Match merupakan salah satu tipe dalam pembelajaran kooperatif yang digunakan untuk mengatasi keterbatasan sarana (Zakaria, Chin, \& Daud, 2010).

\section{Mata Pelajaran Sistem Komputer jurusan TKJ}




\section{a. Jurusan TKJ}

Teknik Komputer Jaringan atau sering disingkat dengan TKJ adalah kemampuan minimal yang harus dibekalkan kepada insan Indonesia (siswa SMK) agar mampu menggunakan komputer sebagai alat bantu untuk mengelola informasi. Tujuan Program Keahlian Teknik Komputer dan Jaringan secara umum mengacu pada isi Undang Undang Sistem Pendidikan Nasional pasal 3 mengenai Tujuan Pendidikan Nasional penjelasan pasal 15 yang menyebutkan bahwa pendidikan kejuruan merupakan pendidikan menengah yang mempersiapkan peserta didik terutama untuk bekerja dalam bidang tertentu.

\section{b. Mata pelajaran Sistem Komputer}

Mata pelajaran sistem komputer merupakan salah satu mata pelajaran Dasar Bidang Keahlian untuk jurusan TKJ. Adapun kompetensi dasar yang digunakan dalam penelitian ini adalah kompetensi dasar sebagai berikut:

1) Memahami sistem bilangan (Desimal, Biner, Oktal, Heksadesimal)

2) Menggunakan sistem bilangan (Desimal, Biner, Oktal, Heksadesimal) dalam memecahkan masalah konversi

3) Memahami relasi logik dan fungsi gerbang dasar (AND, OR, NOT, NAND, EXOR)

4) Merencanakan rangkaian penjumlah dan pengurang dengan gerbang logika (AND, OR, NOT, NAND, EXOR).

Berdasarkan kajian teori dan kerangka berpikir di atas, maka dapat diajukan hipotesis penelitian sebagai berikut:

1. Prestasi belajar siswa dalam sistem komputer pada kompetensi system bilangan dengan menggunakan model pembelajaran kooperatif tipe NHT (Numbered Head Together) lebih baik dibandingkan dengan menggunakan model pembelajaran tipe Make a Match.

2. Prestasi belajar sistem komputer pada kompetensi sistem bilangan siswa yang memiliki tingkat kecerdasan emosional tinggi lebih baik daripada siswa yang memiliki kecerdasan emosional sedang maupun rendah, sedangkan prestasi belajar system computer pada kompetensi system bilangan siswa yang memiliki kecerdasan emosional sedang lebih baik daripada siswa yang memiliki kecerdasan emosional rendah.

3. Terdapat interaksi antara model pembelajaran dengan tingkat kecerdasan emosional siswa terhadap prestasi belajar system computer pada kompetensi system bilangan siswa.

a. Siswa dengan tingkat kecerdasan emosional tinggi, prestasi belajar system computer siswa dengan model pembelajaran NHT sama baiknya dengan prestasi belajar system computer siswa dengan model Make a match

b. Siswa dengan tingkat kecerdasan emosional sedang, prestasi belajar system computer siswa dengan model pembelajaran NHT lebih baik dibandingkan dengan prestasi belajar system computer siswa dengan model Make a match.

c. Siswa dengan tingkat kecerdasan emosional rendah, prestasi belajar system computer siswa dengan model pembelajaran NHT lebih baik dibandingkan dengan prestasi belajar system computer siswa dengan model Make a match.

d. Pada model pembelajaran NHT, prestasi belajar system bilangan siswa yang memiliki tingkat kecerdasan emosional tinggi lebih baik dibandingkan prestasi belajar system computer siswa yang memiliki tingkat kecerdasan emosional sedang dan rendah, dan prestasi belajar system 
computer siswa yang memiliki tingkat kecerdasan emosional sedang lebih baik dibandingkan dengan prestasi belajar system computer siswa yang memiliki tingkat kecerdasan emosional rendah.

Pada model pembelajaran Make a Match, prestasi belajar system bilangan siswa yang memiliki tingkat kecerdasan emosional tinggi lebih baik dibandingkan prestasi belajar system computer siswa yang memiliki tingkat kecerdasan emosional sedang dan rendah, dan prestasi belajar system computer siswa yang memiliki tingkat kecerdasan emosional sedang lebih baik dibandingkan dengan prestasi belajar system computer siswa yang memiliki tingkat kecerdasan emosional rendah.

\section{METODE PENELITIAN}

\section{Tempat dan Waktu Penelitian}

Tempat penelitian adalah tempat yang digunakan dalam melakukan penelitian untuk memperoleh data yang diinginkan. Penelitian ini bertempat di SMKN 1 Kasreman yang berada di Sub Rayon 1 Kabupaten Ngawi jurusan TKJ. Adapun waktu pelaksanan penelitian ini terdiri dari tiga tahap:

1. Tahap persiapan, meliputi: penentuan judul, penyusunan proposal, seminar proposal, revisi proposal, studi pustaka, kualifikasi, pembuatan instrumen mulai bulan Juli sampai dengan September 2013.

2. Tahap pelaksanaan eksperimen, try out dan pengumpulan data. Eksperimen dilakukan selama $12 x$ pertemuan yang terdiri dari 10x pertemuan dengan model pembelajaran NHT (Numbered Head Together) dan Make a Match, sedangkan 2x pertemuan untuk pelaksanaan tes masing-masing model pembelajaran. Tahap pelaksanaan penelitian dilaksanakan selama 3 bulan dimulai bulan Oktober tahun 2013 sampai bulan Desember 2013.

3. Tahap analisis data dan penulisan laporan penelitian. Kegiatan ini dilaksanakan bulan Januari 2014 sampai dengan Februari 2014.

\section{Rancangan Penelitian}

Penelitian ini menggunakan rancangan faktorial $2 \times 3$ dengan teknik analisis variansi (ANAVA). Adapun desain penelitiannya adalah sebagai berikut.

Tabel1.Desain Penelitian Faktorial 2x3

\begin{tabular}{|c|c|c|c|}
\hline \multirow{2}{*}{$\begin{array}{l}\text { Model } \\
\text { Pembelajaran (b) }\end{array}$} & \multicolumn{3}{|c|}{ Kecerdasan Emosional Siswa (b) } \\
\hline & Tinggi $(b)_{1}$ & Sedang $(b)_{2}$ & Rendah(b) 3 \\
\hline $\begin{array}{l}\text { NHT } \\
\left(a_{1}\right)\end{array}$ & $(\mathrm{ab}) 11$ & $(a b)_{12}$ & $(a b)_{13}$ \\
\hline $\begin{array}{l}\text { Make a Match } \\
\left(\mathrm{a}_{2}\right)\end{array}$ & $(a b)_{21}$ & $(a b)_{22}$ & $(a b)_{23}$ \\
\hline
\end{tabular}




\section{Populasi dan Sampel}

Populasi penelitian ini adalah seluruh siswa SMK di Sub Rayon 1 Kabupaten Ngawi jurusan TKJ yang terdiri dari 4 sekolah, yaitu SMKN 1 Ngawi, dan SMKN 1 Kasreman, SMK PGRI 1, SMK Trisakti. Cluster random sampling digunakan untuk memilih secara acak sekolah dan kelas yang akan dipilih menjadi subjek (Budiyono, 2009).. Pemilihan sampel sekolah dilakukan dengan cara undian. Sekolah yang terpilih adalah SMKN 1 Kasreman.Sementara itu, untuk menentukan rombongan belajar digunakan cluster sampling dengan cara undian. Adapun sampel yang ditetapkan sebanyak 2 rombongan belajar. Kelas yang terpilih adalah X TKJ X 1 dan X TKJ 2. Dari kedua kelas tersebut kemudian diundi untuk ditetapkan kelas yang akan diberikan model pembelajaran NHT (Numbered Head Together) dan Make a Match.

\section{Teknik Pengumpulan Data}

1. Instrumen Penelitian

Metode pengumpulan data yang digunakan dalam penelitian ini menggunakan:

\section{a. Metode Dokumentasi}

Fungsi dari metode dokumentasi pada penelitian ini adalah untuk mendapatkan data siswa yang berasal dari nilai ulangan harian pada materi sebelumnya yang digunakan untuk menguji keseimbangan.

\section{b. Metode Angket}

Angket dalam penelitian ini digunakan untuk mengumpulkan data dari variabel kecerdasan emosional siswa. Angket diberikan kepada peserta didik untuk mengetahui skor yang menggambarkan kecerdasan emosional siswa. Angket kecerdasan emosi ini berisi daftar pernyataan yang disusun berdasarkan kisi-kisi dengan rentang 1 sampai 4

\section{c. Metode Tes}

Tes digunakan untuk mengumpulkan data dari variabel prestasi belajar. Tes yang digunakan dalam penelitian ini adalah jenis tes obyektif berbentuk pilihan ganda yang berjumlah 30 butir soal.

\section{Uji Coba Instrumen Penelitian}

Sebelum instrumen penelitian digunakan, baik berupa angket maupun tes terlebih dahulu dilakukan uji coba instrumen yang dikenakan pada populasi di luar sampel penelitian. Dalam penelitian ini, uji coba instrumen dilaksanakan pada siswa kelas X TKJ SMKN 1 Ngawi.

a. Instrumen angket

Hasil uji coba instrumen angket dianalisis untuk mengetahui validitas dan reliabilitasnya.

1) Uji validitas angket

Statistik yang digunakan adalah korelasi "Product Moment".

2) Uji Reliabilitas angket

Untuk menganalisis reliabilitas instrumen angket digunakan rumus Spearman-Brown.

b. Instrumen Tes 
1) Uji validitas Tes

Dalam instrumen tes ini validitas yang digunakan adalah validitas konstruk Untuk mengetahui validitas masing-masing butir soal digunakan rumus korelasi Product Moment dari Pearson

2) Uji Reliabilitas Tes

Reliabilitas pada tes prestasi belajar ini dicari dengan menggunakan rumus dari Kuder dan Richardson (K-R 20).

3) Tingkat Kesukaran

Berdasarkan pedoman bahwa butir soal yang baik untuk menghimpun data penelitian ini mempunyai interval tingkat kesukaran $0,3 \leq P \leq 0,7$ diperoleh kesimpulan bahwa butir soal yang tidak digunakan adalah butir soal nomor 4, 13, 19, 22 dan 27.

4) Daya Beda

Dalam penelitian ini, butir soal dikatakan mempunyai daya beda yang cukup baik jika nilai $d \geq 0.2$.

\section{Teknik Analisis Data}

Sebelum diadakan penelitian antara kelas eksperimen I dan kelas eksperimen II diuji keseimbangannya dengan uji-t. Sebelum dilakukan pengujian hipotesis, lebih dahulu dilakukan uji prasyarat analisis. Data penelitian harus memenuhi uji normalitas, uji homogenitas.

1. Uji Normalitas

Tujuan dilakukan uji normalitas adalah untuk mengetahui apakah data berdistribusi normal atau tidak. Uji normalitas dilakukan dengan menggunakan uji Kolmogorov-Smirnov.

2. Uji homogenitas

Di samping pengujian terhadap normal tidaknya distribusi data pada sampel, dilakukan pula pengujian terhadap kesamaan (homogenitas). Tujuan dilakukan uji homogenitas adalah untuk mengetahui kesamaan variansi. Uji homogenitas untuk kedua kelompok dilakukan dengan menggunakan uji Levene pada taraf signifikansi $a=0.05$.

\section{Pengujian Hipotesis}

Uji hipotesis merupakan metode pengambilan keputusan yang didasarkan pada analisa data hasil penelitian yang berupa angka, sehingga dapat menghasilkan kesimpulan yang dapat memberikan jawaban rumusan masalah yang diajukan secara logis dan sistematis (Azwar, 2011). Dalam penelitian ini, pengujian hipotesis dilakukan dengan menggunakan analisis variansi dua jalan $(2 \times 3)$ dengan frekuensi sel tidak sama pada taraf signifikansi $\alpha=0,05$. Hipotesis statistik yang diajukan dalam penelitian ini adalah sebagai berikut: 
1. Hipotesis $1 \rightarrow$ Ho: $\mu \mathrm{A}_{1}=\mu \mathrm{A}_{2}$

$$
\mathrm{H}_{1}: \mu \mathrm{A}_{1} \neq \mu \mathrm{A}_{2}
$$

2. Hipotesis $2.1 \rightarrow$ Ho: $\mu B_{1}=\mu B_{2}$

$$
\mathrm{H}_{1}: \mu \mathrm{B}_{1} \neq \mu \mathrm{B}_{2}
$$

Hipotesis $2.2 \rightarrow$ Ho: $\mu B_{2}=\mu B_{3}$

$$
\mathrm{H}_{1}: \mu \mathrm{B}_{2} \neq \mu \mathrm{B}_{3}
$$

Hipotesis $2.3 \rightarrow$ Ho: $\mu \mathrm{B}_{1}=\mu \mathrm{B}_{3}$

$$
\mathrm{H}_{1}: \mu \mathrm{B}_{1} \neq \mu \mathrm{B}_{3}
$$

3. Hipotesis $3 \rightarrow \mathrm{Ho}: \mathrm{A} \times \mathrm{B}=0$

$$
\text { Ho : } \mathrm{A} \times \mathrm{B} \neq 0
$$

Keterangan:

$\mu \mathrm{A}_{1} \quad$ :Model Pembelajaran Kooperatif Tipe NHT

HA2 :Model Pembelajaran Kooperatif Tipe Make a Match

uB1 :Tingkat Kecerdasan Emosional Tinggi

$\mu \mathrm{B} 2$ :Tingkat Kecerdasan Emosional Sedang

uB3 :Tingkat Kecerdasan Emosional Rendah

A :Pendekatan model pembelajaran kooperatif

B : :Kecerdasan Emosional Siswa

\section{HASIL DAN PEMBAHASAN}

Berikut ini disajikan deskripsi dari masing-masing data penelitian:

\section{Data Kecerdasan Emosional Siswa}

Tabel 2. Deskripsi Data Kecerdasan Emosional

\begin{tabular}{|c|c|c|c|c|}
\hline \multirow{2}{*}{$\begin{array}{c}\text { Kecerdasan } \\
\text { EQ }\end{array}$} & \multicolumn{2}{|c|}{ Kelas Eksperimen I } & \multicolumn{2}{c|}{ Kelas Eksperimen II } \\
\cline { 2 - 5 } & Frekuensi & Persentase & Frekuensi & Persentase \\
\hline Tinggi & 13 & $36,1 \%$ & 10 & $27,8 \%$ \\
\hline Sedang & 15 & $41,7 \%$ & 12 & $33,3 \%$ \\
\hline Rendah & 8 & $22,2 \%$ & 14 & $38,9 \%$ \\
\hline
\end{tabular}

Dari tabel di atas dapat dilihat bahwa pada kelas eksperimen I siswa yang memiliki kecerdasan emosional tinggi berjumlah 13 anak atau sekitar $36,1 \%$, siswa dengan kecerdasan emosional sedang sejumlah 15 anak dengan prosentase sebesar $41,7 \%$, sedangkan siswa dengan kecerdasan emosional rendah berjumlah 8 anak atau sekitar 22,2\%. Sementara itu, pada kelas eksperimen II siswa yang memiliki kecerdasan emosional tinggi sejumlah 10 anak dengan prosentase $27,8 \%$, siswa dengan 
kecerdasan emosional sedang sejumlah 12 anak dengan prosentase $33,3 \%$ dan siswa dengan kecerdasan emosional rendah berjumlah 14 anak dengan prosentase $38,9 \%$.

\section{Data Prestasi Belajar Siswa}

Tabel 3. Deskripsi Prestasi belajar

\begin{tabular}{|c|c|c|c|c|}
\hline Model & $\begin{array}{c}\text { Kecerdasan } \\
\text { Emosional }\end{array}$ & $\mathbf{N}$ & Rerata & SD \\
\hline \multirow{3}{*}{ NHT } & Tinggi & 13 & 8,92 & 0,619 \\
\cline { 2 - 5 } & Sedang & 15 & 8,51 & 0,691 \\
\cline { 2 - 5 } & Rendah & 8 & 7,64 & 0,858 \\
\hline \multirow{3}{*}{ MAM } & Tinggi & 10 & 7,67 & 0,943 \\
\cline { 2 - 5 } & Sedang & 12 & 7,52 & 0,919 \\
\cline { 2 - 5 } & Rendah & 14 & 7,38 & 0,839 \\
\hline
\end{tabular}

Dari tabel di atas dapat dilihat bahwa siswa dengan kecerdasan emosional tinggi memiliki prestasi belajar yang baik pula. Pada kelas eksperimen I, siswa dengan kecerdasan emosional tinggi reratanya sebesar 8,92 dengan standar deviasi 0,619. Untuk siswa dengan kecerdasan emosional sedang, maka reratanya sebesar 8,51 dengan standar deviasi 0,858. Sedangkan rerata sebesar 7,64 dengan standar deviasi sebesar 0,943 adalah bagi kelompok siswa dengan tingkat kecerdasan emosional rendah. Sementara itu, untuk kelas eksperimen II, siswa dengan kecerdasan emosional tinggi reratanya sebesar 7,67 dengan standar deviasi 0,943 . Untuk siswa dengan kecerdasan emosional sedang, maka reratanya sebesar 7,52 dengan standar deviasi 0,919. Sedangkan rerata sebesar 7,38 dengan standar deviasi sebesar 0,839 adalah bagi kelompok siswa dengan tingkat kecerdasan emosional rendah. Dengan demikian berdasarkan tabel di atas dapat diketahui bahwa rerata hasil belajar siswa yang menggunakan model pembelajaran NHT (Numbered Head Together) baik pada tingkat kecerdasan emosional tinggi, sedang maupun rendah lebih baik daripada kelompok yang menggunakan model pembelajaran MAM (Make a Match), meskipun pada tingkat kecerdasan rendah tidak terpaut terlalu jauh.

\section{Pengujian Prasyarat Analisis}

a. Uji Normalitas

Tabel 4. Hasil perhitungan Uji Normalitas

\begin{tabular}{|l|c|c|}
\hline \multicolumn{1}{|c|}{ Kelompok Data } & Sig. & Kesimpulan \\
\hline \hline Kelas eksperimen 1(NHT) & 0,305 & normal \\
\hline Kelas eksperimen 2(Make a Match) & 0,058 & normal \\
\hline
\end{tabular}

Berdasarkan data pada tabel terlihat bahwa semua kelompok sampel mempunyai nilai signifikansi yang lebih besar dari alpha yang ditetapkan, yaitu $5 \%$. Dapat disimpulkan bahwa semua kelompok sampel berasal dari populasi yang berdistribusi normal.

b. Uji Homogenitas

Tabel 5. Hasil perhitungan Uji Homogenitas

\begin{tabular}{|c|c|c|c|}
\hline $\mathrm{F}$ & df1 & $\mathrm{df} 2$ & Sig. \\
\hline 1,207 & 5 & 66 &, 315 \\
\hline
\end{tabular}


Nilai signifikansi hasil untuk semua data pada semua variabel lebih dari 0,05. Dengan demikian, dapat disimpulkan bahwa varians pada kedua kelas eksperimen adalah sama atau homogen.

c. Uji ANAVA

Tabel 6. Hasil perhitungan Uji ANAVA

\begin{tabular}{|c|c|c|c|c|c|}
\hline Source & $\begin{array}{l}\text { Type III Sum } \\
\text { of Squares }\end{array}$ & df & Mean Square & $\mathrm{F}$ & Sig. \\
\hline Corrected Model & $27,686(a)$ & 5 & 5,537 & 9,037 &, 000 \\
\hline Intercept & 4316,815 & 1 & 4316,815 & 7045,541 &, 000 \\
\hline Kecerdasan_Emosional & 9,492 & 2 & 4,746 & 7,746 & 001 \\
\hline Model_Pembelajaran & 10,418 & 1 & 10,418 & 17,003 &, 000 \\
\hline $\begin{array}{l}\text { Kecerdasan_Emosional * } \\
\text { Model_Pembelajaran }\end{array}$ & 3,962 & 2 & 1,981 & 3,233 &, 046 \\
\hline Error & 40,438 & 66 &, 613 & & \\
\hline Total & 4650,560 & 72 & & & \\
\hline Corrected Total & 68,124 & 71 & & & \\
\hline
\end{tabular}

Tabel di atas menyajikan hasil pengujian data dengan anava dua jalan dengan isi sel tidak sama. Analisis hasil penelitian menggunakan taraf signifikan $a=0,05$. Kriteria uji yang ditetapkan adalah jika nilai signifikan < a $(0,05)$, maka $\mathrm{HO}$ ditolak dan $\mathrm{H} 1$ diterima yang berarti ada pengaruh yang signifikan dari perlakuan terhadap prestasi belajar peserta didik.

d. Uji Lanjut Analisis Varian

Tabel 7. Rangkuman Keputusan uji Lanjut Antar Sel (NHT)

\begin{tabular}{|c|c|c|c|}
\hline Komparasi & $\begin{array}{c}\text { Perbedaan } \\
\text { nilai rata-rata }\end{array}$ & $\begin{array}{l}\text { Statistik Uji } \\
\text { (Sig.) }\end{array}$ & Kesimpulan \\
\hline $\begin{array}{l}\text { NHT - kecerdasan emosi tinggi } \\
\text { dengan } \\
\text { NHT - kecerdasan emosi sedang }\end{array}$ & 0,363 & 0,824 & $\begin{array}{c}\text { Tidak } \\
\text { berbeda } \\
\text { signifikan }\end{array}$ \\
\hline $\begin{array}{l}\text { NHT - kecerdasan emosi tinggi } \\
\text { dengan } \\
\text { NHT - kecerdasan emosi rendah }\end{array}$ & 1,473 & 0,001 & $\begin{array}{l}\text { Berbeda } \\
\text { signifikan }\end{array}$ \\
\hline $\begin{array}{l}\text { NHT - kecerdasan emosi sedang } \\
\text { dengan } \\
\text { NHT - kecerdasan emosi rendah }\end{array}$ & 1,110 & 0,022 & $\begin{array}{c}\text { Berbeda } \\
\text { signifikan }\end{array}$ \\
\hline
\end{tabular}

Tabel 8. Rangkuman Keputusan uji Lanjut Antar Sel (MAM)

\begin{tabular}{|c|c|c|c|}
\hline Komparasi & $\begin{array}{c}\text { Perbedaan } \\
\text { nilai rata-rata }\end{array}$ & $\begin{array}{c}\text { Statistik Uji } \\
\text { (Sig.) }\end{array}$ & Kesimpulan \\
\hline $\begin{array}{c}\text { MAM - kecerdasan emosi tinggi } \\
\text { dengan }\end{array}$ & 0,293 & 0,951 & $\begin{array}{c}\text { Tidak } \\
\text { berbeda } \\
\text { signifikan }\end{array}$ \\
\hline MAM - kecerdasan emosi sedang & 0,389 & 0,836 & $\begin{array}{c}\text { Tidak } \\
\text { berbeda } \\
\text { signifikan }\end{array}$ \\
\hline $\begin{array}{c}\text { MAM - kecerdasan emosi rendah } \\
\text { dengan }\end{array}$ & 0,095 & 1,000 & $\begin{array}{c}\text { Tidak } \\
\text { berbeda } \\
\text { signifikan }\end{array}$ \\
\hline $\begin{array}{c}\text { MAM - kecerdasan emosi sedang } \\
\text { dengan }\end{array}$ & & \\
MAM - kecerdasan emosi rendah
\end{tabular}




\section{HASIL DAN PEMBAHASAN}

Dari hasil pengujian hipotesis di atas dapat dikemukakan pembahasan terhadap hasil penelitian yang didasarkan pada hasil analisis data hasil prestasi belajar Sistem Komputer pada materi Sistem Bilangan Dan Relasi Logik Gerbang Logika sebagai berikut

1. Hipotesis pertama

Hasil pengujian pada Uji Anava diperoleh bahwa model pembelajaran kooperatif tipe NHT (Numbered Head Together) lebih baik dari model pembelajaran Make a Match (MAM). Hal ini dapat dilihat dari rata-rata pada hasil prestasi dengan model pembelajaran NHT yang lebih besar dari dibandingkan dengan model pembelajaran MAM. Maka dapat disimpulkan bahwa pembelajaran NHT lebih baik dibandingkan pembelajaran MAM terhadap penguasaan kompetensi Sistem Komputer. Dengan demikian hipotesis 1 terbukti (Mustafa \& Baharuddin, 2011).

\section{Hipotesis kedua}

Hasil pengujian dengan Uji Anava diperoleh kesimpulan bahwa hasil prestasi belajar pada siswa yang memiliki tingkat kecerdasan emosional tinggi lebih baik dibandingkan siswa yang memiliki tingkat kecerdasan emosional sedang atau rendah dan prestasi belajar Sistem Komputer siswa yang memiliki tingkat kecerdasan emosi sedang lebih baik dibandingkan siswa yang memiliki tingkat emosional yang rendah. Dari hasil uji analisis variansi diperoleh nilai signifikansi 0,001 yang lebih kecil dari 0,05. Dengan demikian hipotesis 2 terbukti.

\section{Hipotesis ketiga}

Hasil pengujian pengaruh bersama (interaksi) ditemukan bahwa penerapan model pembelajaran dan kecerdasan emosional siswa secara bersama-sama mempengaruhi prestasi hasil belajar. Dari hasil Uji Anava menunjukkan nilai signifikansi 0,046 <0,05. Dengan demikian hipotesis 3 terbukti.

\section{KESIMPULAN DAN SARAN}

\section{Kesimpulan}

Berdasarkan data hasil penelitian yang telah dianalisis dan pembahasan data hasil penitian maka dapat ditarik kesimpulan dari hasil penelitian adalah sebagai berikut:

1. Terdapat perbedaan pengaruh antara penggunaan model pembelajaran kooperatif tipe NHT (Numbered Head Together) dan Make a Match terhadap prestasi belajar siswa. Prestasi belajar siswa pada mata pelajaran Sistem Komputer dengan menggunakan model pembelajaran kooperatif tipe NHT (Numbered Head Together) lebih baik dibandingkan dengan prestasi belajar siswa dengan menggunakan model pembelajaran kooperatif tipe Make a Match. Dengan demikian model pembelajaran kooperatif tipe NHT (Numbered Head Together) mempunyai pengaruh yang lebih baik terhadap penguasaan materi Sistem Komputer dibanding model pembelajaran kooperatif tipe MAM (Make a Match).

2. Terdapat perbedaan prestasi belajar siswa yang memiliki kecerdasan emosional tinggi, sedang dan rendah pada mata pelajaran sistem komputer. Prestasi hasil belajar siswa pada pelajaran Sistem Komputer untuk siswa dengan kecerdasan emosional tinggi lebih baik dibandingkan dengan hasil belajar siswa dengan kecerdasan emosional sedang atau rendah. Hasil belajar siswa dengan kecerdasan emosional sedang lebih baik dibandingkan dengan hasil belajar siswa dengan kecerdasan emosional rendah. Sehingga dapat disimpulkan tingkat kecerdasan emosional siswa mempunyai pengaruh terhadap penguasaan kompetensi Sistem Komputer. 
3. Terdapat interaksi pengaruh antara penggunaan model pembelajaran kooperatif tipe NHT (Numbered Head Together) dan Make a Match dengan tingkat kecerdasan emosional siswa terhadap prestasi belajar siswa dalam mata pelajaran Sistem Komputer ditinjau dari kecerdasan emosional siswa.

a. Siswa dengan tingkat kecerdasan emosional tinggi memperoleh prestasi belajar pada pembelajaran Sistem Komputer yang lebih baik dibandingkan dengan menggunakan model pembelajaran kooperatif tipe NHT (Numbered Head Together) maupun Make a Match.

b. Siswa dengan tingkat kecerdasan emosional sedang pada pembelajaran Sistem Komputer dengan model pembelajaran kooperatif tipe NHT (Numbered Head Together) memperoleh prestasi yang lebih baik jika dibandingkan dengan menggunakan model pembelajaran kooperatif tipe Make a Match.

c. Siswa dengan tingkat kecerdasan emosional rendah pada pembelajaran Sistem Komputer dengan model pembelajaran kooperatif tipe NHT (Numbered Head Together) memperoleh prestasi yang tidak lebih baik jika dibandingkan dengan menggunakan model pembelajaran kooperatif tipe Make a Match.

d. Pada model pembelajaran kooperatif tipe NHT (Numbered Head Together), prestasi belajar siswa pada pembelajaran Sistem Komputer dengan tingkat kecerdasan emosional tinggi memperoleh hasil yang tidak lebih baik dibandingkan dengan prestasi siswa yang memiliki tingkat kecerdasan emosional sedang, namun memperoleh hasil yang lebih baik dibandingkan dengan prestasi siswa yang memiliki tingkat kecerdasan emosional rendah. Sedangkan prestasi belajar siswa dengan tingkat kecerdasan emosional sedang mendapatkan hasil yang lebih baik dibandingkan dengan siswa dengan tingkat kecerdasan rendah.

e. Pada model pembelajaran kooperatif tipe Make a Match, prestasi belajar siswa pada pembelajaran Sistem Komputer dengan tingkat kecerdasan emosional tinggi memperoleh hasil yang tidak lebih baik dibandingkan dengan prestasi siswa yang memiliki tingkat kecerdasan emosional sedang maupun rendah dan prestasi belajar siswa dengan tingkat kecerdasan emosional sedang mendapatkan hasil yang tidak lebih baik dibandingkan dengan siswa dengan tingkat kecerdasan rendah.

\section{Saran}

Bagi Kepala Sekolah sebagai penentu kebijakan ditingkat sekolah hendaknya : Memfasilitasi dan selalu memberikan motivasi kepada para guru untuk selalu mengembangkan pembelajaran melalui model pembelajaran yang menarik bagi siswanya. Bagi Guru, model pembelajaran kooperatif tipe NHT (Numbered Head Together) terbukti dapat meningkatkan prestasi belajar siswa dalam kompetensi Sistem Komputer, oleh karena itu guru disarankan untuk menerapkannya dalam proses pembelajaran. Kecerdasan emosional merupakan faktor yang berperan dalam keberhasilan proses pembelajaran, oleh karena itu guru perlu membangun kecerdasan emosi siswa selama proses pembelajaran.

\section{DAFTAR PUSTAKA}

Agustian, A. G. (2003). ESQ Power Sebuah Inner Journey. Jakarta: ESQ

Alder, H. (2001). Boost Your Intelligence: Pacu EQ dan IQ. terj. Christina Prianingsih. Jakarta: Erlangga.

Ali, R., et al (2011). The impact of motivation on students ' academic achievement in mathematics in problem-based learning environment. International Journal Of Academic Research (Online). 3(1), 306-309.

Rohman, A. (2009). Memahami Pendidikan dan IImu Pendidikan. Yogyakarta: Laksbang Mediatama. 
Azwar, S. (2011). Tes Prestasi. Yogyakarta: Pustaka Pelajar.

Budiyono. (2009). Statistika untuk Penelitian. Surakarta: UNS Press.

Berenson, R. at.al. (2008). Emotional Intelligence as a predictor for success in online learning. The International Review of research in open and distance learning (Online). 9(2):1-17.

Chen, C, et al. (2012). A Collaborative Cross Number Puzzle Game to Enhance Elementary Students' Arithmetic Skills. The Turkish Online Journal of Educational Technology (Online). II (2), 1-14.

Ferguson, K. P. (2011). Cooperative Learning and Quality Teaching: Early career teachers striving for quality. The International Journal of Learning (Online), 16, (12) :385-400.

Goleman, D. (2005). Working With Emotional Intelligence (terjemahan Alex Tri Kantjono Widodo. Jakarta: Gramedia Utama. cet vi, hlm. 512

Iqbal, M. J, Kousar, M. N, Rahman, F. (2011). Collaborative Learning Strategies: Potential Application in Distance Education. International Journal of Business and Social Science (Online), 2 (12), 253.

Kane, E. M. (2013). Urban Student Motivation through Inquiry-Based Learning. Journal of Studies in Education (Online), 3(1), 155.

Mahedy, L at. al. (2006). The Effect of Numbered Heads Together with and without an Incentive package on the Science test Performance of a Diverse Group of sixth Graders. Journal of behavioral Education, 15(1), 25-39

Mustafa, Y \& Baharuddin. (2011). Penerapan Pembelajaran Kooperatif Model Numbered head together (NHT) Untuk Meningkatkan Keaktifan dan Penguasaan Konsep Matematika. Jurnal PTK Decentralized Basic Education, 3(1), 8 - 14.

Zakaria, E., Chin, L.C., \& Daud, M. Y. (2010). The effect of cooperative Learning on students' Mathematics Achievement and attitude towards mathematics. Journal of social science, 6(2), 272-275. 